\title{
MEMBANGUN SISTEM PENDUKUNG KEPUTUSAN BIRO PERJALANAN HAJI DAN UMRAH DI YOGYAKARTA MENGGUNAKAN METODE SIMPLE ADDITIVE WEIGHTING
}

\author{
Landung Sudarmana \\ Program Studi Manajemen Informatika \\ STMIK Jenderal Achmad Yani Yogyakarta \\ Email: willerkasani@gmail.com \\ Wakhid Sulthani Aziz Komara Putra \\ Program Studi Teknik Informatika \\ STMIK Jenderal Achmad Yani Yogyakarta \\ Email: un_jos@yahoo.com
}

\begin{abstract}
ABSTRAK
Biro perjalanan haji dan umrah adalah suatu bentuk perusahaan jasa yang bertujuan untuk membantu calon jama'ah dalam melaksanakan ibadah haji dan umrah. Dalam prosesnya, perusahaan biro perjalanan haji dan umrah akan memberikan penawaran berupa paket perjalanan ibadah haji maupun umrah yang dapat dipilih sendiri oleh calon jama'ah. Banyaknya biro perjalanan haji dan umrah di Yogyakarta menuntut keselektifan calon jama'ah dalam memilih biro perjalanan haji dan umrah yang akan digunakan, agar terhindar dari biro jasa yang tidak profesional yang dapat menimbulkan kerugian bagi calon jama'ah di kemudian hari, seperti penipuan, jama'ah haji ilegal maupun sarana dan prasarana yang tidak layak selama melaksanakan ibadah haji dan umrah. Namun untuk mensurvei satu persatu biro jasa perjalanan haji dan umrah yang ada di Yogyakarta membutuhkan waktu dan tenaga yang tidak sedikit, hal inilah yang menyebabkan kecenderungan calon jama'ah malas untuk melakukannya. Penelitian ini bertujuan untuk membangun sebuah sistem yang dapat memberikan rekomendasi bagi calon jama'ah dalam memilih biro perjalanan haji dan umrah di Yogyakarta secara online. Sistem ini dirancang berbasis web menggunakan bahasa pemrograman PHP dan MySql sebagai database engine dengan Simple Additive Weighting sebagai metode untuk mencari alternatif terbaik bedasarkan kriteriakriteria yang telah ditentukan. Sistem pendukung keputusan ini memiliki tiga hak akses yang berbeda yaitu admin, biro haji dan calon jama'ah haji dan dapat diakses secara online. Admin memiliki hak untuk mengelola seluruh data yaitu data profil biro, data peket perjalanan, data kriteria, data subkriteria dan data rating kecocokan. Biro haji memiliki hak mengelola datanya sendiri dengan cara login dahulu. Calon jama'ah memilki hak melakukan perekomendasian dan melihat informasi profil biro yang sudah terdaftar dalam sistem. Sistem ini telah berjalan dengan baik, antara lain dapat membantu calon jama'ah dalam memilih biro jasa perjalanan haji dan umrah yang akan digunakan secara lebih efektif dan efisien, serta dapat menjadi media promosi bagi perusahaan biro jasa perjalanan haji dan umrah.
\end{abstract}

Kata kunci: haji dan umrah, sistem pendukung keputusan, metode simple additive weighting.

\section{ABSTRACT}

This Hajj and Umrah travel agencies is a form of service company that aims to help prospective pilgrims in the Hajj and Umrah. In the process, travel agencies Hajj and Umrah will offer a package of Hajj and Umrah trip to handpicked by prospective pilgrims. The number of Hajj and Umrah travel agencies in Yogyakarta demanding selectivity in choosing a candidate pilgrims Hajj and Umrah travel agencies that will be used, to avoid unprofessional service bureau that can cause harm to potential worshipers at a later date, such as fraud, jama 'ah illegal hajj and infrastructure is not feasible during Hajj and Umrah. But one by one agency for surveying services Hajj and Umrah trip in Yogyakarta takes time and effort is not small, it is this which causes the likelihood of a prospective pilgrims lazy to do so. This research aims to develop a system that can provide recommendations for prospective pilgrims in choosing a travel agency Hajj and Umrah in Yogyakarta online. The system is designed to use web based PHP programming language and MySQL as the database engine with Simple Additive weighting as a method for finding the best alternative based on predetermined criteria. This decision support system has three different permissions that administrators, agencies and prospective Haj pilgrims and can be accessed online. Admin has the right to manage all the data that the bureau profile data, trip peket the data, the data criteria, sub-criteria of data and data compatibility rating. Hajj Bureau has the right 
manage their own data by logging in first. Candidates have the right to do perekomendasian congregation and see the agency profile information that is already registered in the system. This system has worked well, among others, can help prospective pilgrims in selecting a service bureau Hajj and Umrah to be used more effectively and efficiently, and can be a media campaign for the enterprise service bureaus and Umrah pilgrimage.

Keywords: hajj and umrah, decicion support system, simple additive weighting method.

\section{PENDAHULUAN}

Haji merupakan rukun Islam yang kelima dan menjadi kewajiban bagi setiap orang Islam untuk melaksanakannya, terutama yang memiliki kemampuan, baik secara finansial maupun kesehatan jasmani [8]. Terlebih Indonesia merupakan negara dengan penduduk Muslim terbanyak di dunia. Berdasarkan sensus penduduk yang dilakukan oleh Badan Pusat Statistik (BPS) pada tahun 2010, tercatat sebanyak 207.176.162 jiwa penduduk Indonesia memeluk agama Islam yang jika dipersentasekan setara dengan $87,18 \%$ dari total penduduk Indonesia yang berjumlah 237.641.326 jiwa. Tercatat 168.800 jama'ah haji telah diberangkatkan ke Makkah pada tahun 2014 lalu, dengan 2.471 jama'ah haji berasal dari Yogyakarta.

Seiring dengan antusiasme penduduk muslim untuk melaksanakan ibadah haji maupun umrah, sekarang ini banyak bermunculan biro jasa perjalanan haji dan umrah di Indonesia, lebih khususnya di Yogyakarta. Hal ini sangat membantu bagi calon jama'ah haji karena dapat merencanakan ibadah hajinya sesuai dana yang dimiliki dan fasilitas yang diinginkan seperti kota keberangkatan, transportasi yang digunakan, durasi perjalanan, penginapan yang disediakan, konsumsi dan fasilitas pendukung lainnya selama melaksanakan ibadah haji. Namun tidak semua biro jasa perjalanan ibadah haji dan umrah ini bersifat legal dan profesional. Banyak kasus yang terjadi karena tidak cermat dalam memilih biro jasa perjalanan haji dan umrah, diantaranya jama'ah haji illegal, jama'ah haji terlantar, penginapan yang tidak layak, makanan yang tidak sehat dan masih bayak lagi kasus-kasus lainnya yang menimpa para jama'ah haji. Oleh karena itu, hendaknya calon jama'ah haji harus selektif dalam menentukan biro jasa perjalanan haji dan umrah mana yang akan digunakan. Namun terkadang calon jama'ah haji terlalu sibuk dengan pekerjaan maupun kehidupan sehari-harinya sehingga tidak mempunyai waktu untuk mensurvei satupersatu biro jasa perjalanan haji dan umrah mana yang sesuai dengan keinginan.

Perkembangan dan penggunaan teknologi komputer telah merambah ke berbagai bidang yang tidak dapat dihindari. Salah satu bentuknya ialah Sistem Pendukung Keputusan (SPK). Sistem ini adalah suatu sistem berbasis komputer yang menghasilkan berbagai alternatif keputusan untuk membantu dalam menangani berbagai permasalahan yang semi terstruktur ataupun tidak terstruktur dengan menggunakan data dan model [3].

Penelitian sistem pendukung keputusan biro perjalanan haji ini dirancang berdasarkan penelitianpenelitian terkait yang telah dilakukan sebelumnya, antara lain :

"Sistem Pendukung Keputusan Seleksi Dana Talangan Calon Jama'ah Haji Pada Bank Muamalat Kepri” [4]. Penelitian ini menghasilkan sistem berbasis dekstop yang membahas tentang penginputan, penyediaan, pengecekan kelayakkan dan laporan data angsuran yang akan menghasilkan output calon jama'ah haji yang layak mendapatkan dana talangan. Terdapat fasilitas login sebagai petugas dan manajer, form calon haji dan form seleksi

"Pemodelan Sistem Pendukung Keputusan Dengan Metode Kombinasi Fuzzy Tahani Dan Simple Additive Weighting" [2]. Penelitian ini membahas tentang sistem pendukung keputusan untuk perekrutan Pegawai Negeri Sipil Daerah (PNSD) di Pemerintahan Provinsi Aceh berdasarkan 4 buah kriteria yaitu Usia, Ijazah, SK Dinas dan Masa Aktif. Output sistem yang berbasis dekstop ini berupa hasil perangkingan data pegawai honorer di lingkungan Pemerintahan Propinsi Aceh khususnya di Kabupaten Bireuen yang merupakan prioritas utama menjadi PNSD.

"Sistem Pendukung Keputusan Pemilihan Karyawan Terbaik Dengan Metode Simple Additive Weighting [1]. Penelitian ini membahas tentang prosedur penilaian dan pemilihan karyawan terbaik pada Pamella Swalayan Yogyakarta serta untuk menghasilkan sistem pendukung keputusan pemilihan karyawan terbaik berdasarkan kriteria - kriteria yang telah ditentukan yaitu kejujuran, taat peraturan, mangkir/alpha, kedisiplinan, tanggung jawab, kebersihan, kerajinan, kreatifitas, kerjasama dan senyuman. Terdapat fasilitas login, form karyawan masuk, form karyawan keluar, form penilaian karyawan dan cetak data. Sistem pendukung keputusan ini berbasiskan dekstop.

Berdasarkan referensi tersebut, penelitian ini dibangun dengan konsep yang sama, yaitu menggunakan metode SAW namun kasus yang diangkat berbeda, yaitu pemilihan biro perjalanan haji. Perbedaan lainnya adalah sistem pendukung keputusan ini berbasis web. 
Banyak metode yang dapat digunakan SPK dalam menyelesaikan masalah Multi Attribute Decision Making (MADM), salah satunya adalah Simple Additive Weighting (SAW). Metode ini dapat menentukan nilai bobot untuk setiap atribut, kemudian dilanjutkan dengan proses perankingan yang akan menyeleksi alternatif terbaik dari sejumlah alternatif sehingga akan mendapatkan hasil yang lebih akurat karena didasarkan pada nilai kriteria dan bobot yang sudah ditentukan [5].

Dari latar belakang diatas, kasus pemilihan biro jasa perjalanan haji di Yogyakarta digolongkan permasalahan semiterstruktur dan dapat diselesaikan dengan menggunakan SPK untuk menghasilkan keputusan terbaik bagi calon jama'ah haji maupun umrah dalam memilih biro perjalanan haji yang diinginkan dengan lebih cepat, mudah dan akurat sesuai kriteria yang telah ditentukan, seperti harga, durasi perjalanan, jumlah orang sekamar dan fasilitas. Selain itu, sistem ini bisa menjadi media promosi bagi biro perjalanan haji dan umrah di Yogyakarta, dengan mendeskripsikan paket-paket perjalanan haji yang ditawarkan, lokasi perusahaan, kontak person yang dapat diubah sewaktu-waktu oleh perusahaan itu sendiri, dengan syarat sudah terdaftar dan terverifikasi didalam sistem.

\section{METODOLOGI PENELITIAN}

\subsection{Bahan Penelitian}

Penelitian ini akan menggali data informasi dari berbagai sumber. Sumber utama didapat dari birobiro perjalanan haji yang terdapat di Yogyakarta, baik melalui wawancara maupun dengan mengakses website. Selain itu untuk menjaga kualitas data, informasi juga akan diperoleh dari Kementerian Agama. Agar biro-biro perjalanan haji yang akan dijadikan sampel benar-benar legal dan terdaftar di Kementerian Agama Yogyakarta.

\subsection{Alat Penelitian}

Alat yang digunakan dalam penelitian ini adalah komputer dengan spesifikasi cukup untuk menjalankan sistem operasi dan perangkat lunak pengembangan sistem serta koneksitas internet. Sistem Operasi dan program-program aplikasi yang dipergunakan dalam dalam pengembangan sistem ini adalah: bahasa pemrogramana: PHP, sistem operasi: windows 8.1, text editor: notepad++, SQL manager: wampserver 2.5 , software pendukung: mozilla firefox.

\subsection{Metode Simple Additive Weighting}

Metode Simple Additive Weighting (SAW) merupakan salah satu metode untuk penyelesaian masalah Multi Attribute Decision Making [6]. Metode SAW sering dikenal dengan istilah metode penjumlahan terbobot. Konsep dasar metode SAW adalah mencari penjumlahan terbobot dari rating kinerja pada setiap alternatif pada semua atribut. Metode SAW dapat membantu dalam pengambilan keputusan suatu kasus, akan tetapi perhitungan dengan menggunakan metode SAW ini hanya yang menghasilkan nilai terbesar yang akan terpilih sebagai alternatif yang terbaik. Perhitungan akan sesuai dengan metode ini apabila alternatif yang terpilih memenuhi kriteria yang telah ditentukan.

Metode SAW ini lebih efisien karena waktu yang dibutuhkan dalam perhitungan lebih singkat. Metode SAW membutuhkan proses normalisasi matriks keputusan $(X)$ ke suatu skala yang dapat diperbandingkan dengan semua rating alternatif yang ada.

\subsubsection{Kelebihan dan Kekurangan Metode SAW}

1) Kelebihan:

a. Menentukan nilai bobot untuk setiap atribut, kemudian dilanjutkan dengan proses perangkingan yang akan menyeleksi alternative terbaik dari sejumlah alternatif.

b. Penilaian akan lebih tepat karena didasarkan pada nilai kriteria dan bobot preferensi yang sudah ditentukan.

2) Kekurangan:

a. Perhitungan dilakukan dengan menggunakan bilangan crisp.

b. Adanya perbedaan perhitungan normalisasi matriks sesuai dengan nilai atribut (antara nilai benefit dan cost).

\subsubsection{Langkah Penyelesaian Metode SAW}

Berikut adalah langkah penyelesaian metode SAW : 
1) Menentukan kriteria-kriteria yang akan dijadikan acuan dalam pengambilan keputusan, yaitu $\mathrm{Ci}$.

2) Menentukan rating kecocokan setiap alternatif pada setiap kriteria.

3) Membuat matriks keputusan berdasarkan kriteria ( $\mathrm{Ci}$ ), kemudian melakukan normalisasi matriks berdasarkan persamaan yang disesuaikan dengan jenis atribut (atribut keuntungan ataupun atribut biaya) sehingga diperoleh matriks ternormalisasi $R$.

4) Hasil akhir diperoleh dari proses perankingan yaitu penjumlahan dari perkalian matriks ternormalisasi $R$ dengan vektor bobot sehingga diperoleh nilai terbesar yang dipilih sebagai alternatif terbaik $(A i)$ sebagai solusi.

Formula untuk melakukan normalisasi tersebut adalah:

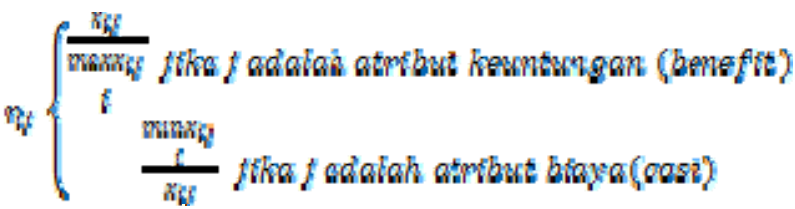

Keterangan:

rij $=$ rating kinerja ternormalisasi

max xij = nilai maksimum dari setiap baris dan kolom

min $x i j=$ nilai minimum dari setiap baris dan kolom

$\mathrm{xij}=$ baris dan kolom dari matriks

Dengan rij adalah rating kinerja ternormalisasi dari alternatif $A i$ pada atribut $C j ; i=1,2, \ldots, m$ dan $j=$ $1,2, \ldots, n$. Nilai preferensi untuk setiap alternatif $(V i)$ diberikan sebagai:

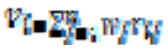

Keterangan :

$\mathrm{Vi}=$ Nilai akhir dari alternatif

$\mathrm{wj}=$ Bobot yang telah ditentukan

rij $=$ Normalisasi matriks

Nilai $V i$ yang lebih besar mengindikasikan bahwa alternatif $A i$ lebih terpilih.

\subsection{Jalan Penelitian}

Perancangan sistem pendukung keputusan mengunakan metode waterfall. Teknik ini dipilih karena pengembangan sistem yang dilakukan lebih terstruktur dengan adanya tahap-tahap yang dilakukan secara terurut dan setiap tahap harus diselesaikan terlebih dahulu untuk menghindari terjadinya pengulangan dalam tahapan sehingga pengembangan sistem yang dilakukan dapat memperoleh hasil yang diinginkan [7], dan tahapan metode waterfall pada gambar 1.

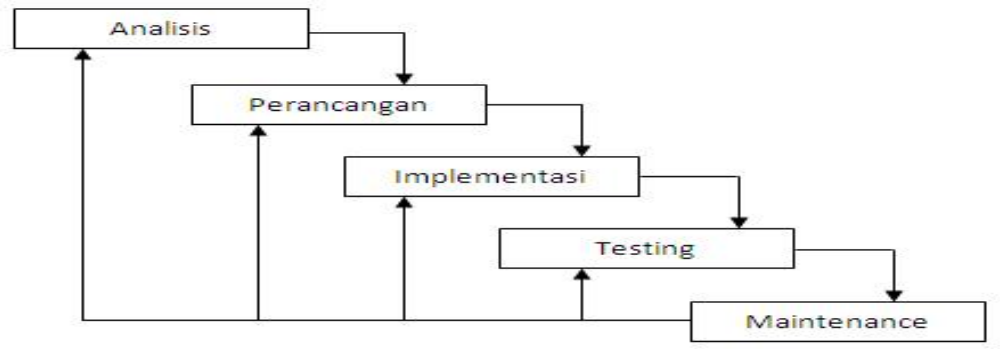

Gambar 1. Tahapan Metode Waterfall

1) Tahap Analisis Kebutuhan

Terdiri dari pengumpulan data biro jasa haji dan umran d1 Y ogyakarta, ba1k dari internet maupun wawancara dengan mendatangi biro jasa haji dan umrah yang akan dijadikan sampel. 


\section{2) Tahap Perancangan}

Pada tahap ini desain sistem mulai dibangun meliputi data flow diagram (DFD), entity relationship diagram (ERD), basis data, struktur tabel, dan antar muka (interface). Desain ini dimulai sebelum tahap implementasi.

\section{3) Tahap Implementasi}

Tahap dimana penulisan kode program mulai dilakukan. Tahap implementasi dimulai setelah tahap desain sistem sudah terselesaikan.

\section{4) Tahap Testing}

Tahap dimana dilakukannya testing atau pengujian terhadap sistem yang dibangun. Setelah semua fitur dalam sistem berjalan sebagaimana fungsinya, selanjutnya akan di-publish secara online agar dapat digunakan oleh semua pengguna.

5) Tahap Pemeliharaan (maintenance)

Tahap ini merupakan tahap terakhir dari metode waterfall, dimana sistem yang sudah dijalankan dan di-publish akan dilakukan pemeliharaan. Pada tahap ini juga dilakukan perbaikan kesalahan-kesalahan yang sebelumnya tidak ditemukan.

\section{HASIL DAN PEMBAHASAN}

Sistem pendukung keputusan pemilihan biro jasa perjalanan haji dan umrah di Daerah Istimewa Yogyakarta adalah sebuah sistem yang berfungsi sebagai alat bantu bagi calon jama'ah haji maupun umrah dalam memilih biro jasa yang sesuai dengan kriteria yang telah ditentukan, namun keputusan akhir tetap pada calon jama'ah itu sendiri karena sistem hanya memberikan rekomendasi. Terdapat 4 kriteria yang menjadi penentu hasil perekomendasian, yaitu harga, durasi perjalanan, jumlah orang sekamar dan fasilitas. Selain itu, sistem pendukung keputusan ini juga dapat menjadi media promosi bagi biro jasa haji dan umrah dalam mengiklankan paket perjalanan yang dimiliki

\subsection{Pengujian Perhitungan Metode SAW}

Perhitungan yang dilakukan mengambil contoh kasus dalam pemilihan jenis ibadah haji plus, kriteria yang dijadikan acuan dalam proses perekomendasian biro pada tabel 1 .

Tabel 1. Tabel kriteria

\begin{tabular}{ll}
\hline Kode & Kriteria \\
\hline C1 & Harga \\
C2 & Durasi Perjalanan \\
C3 & Jumlah Orang Sekamar \\
C4 & Fasilitas \\
\hline
\end{tabular}

Dari kriteria-kriteria, hanya kriteria C2 sampai C4 yang akan diberikan bobot, sedangkan kriteria C1 tidak diberikan bobot karena menggunakan input-an data asli. Di bawah ini adalah bobot pada kriteria $\mathrm{C} 2$ sampai C4 yang dinilai dengan angka 1 (satu) sampai 5 (lima) yang ditentukan dengan menggunakan pendekatan subjektivitas seperti yang tertera pada tabel 2 .

\section{Tabel 2. Tabel bobot kriteria}

\begin{tabular}{cc}
\hline Bobot & Keterangan \\
\hline 1 & Sangat Kurang \\
2 & Kurang \\
3 & Cukup \\
4 & Baik \\
5 & Sangat Baik \\
\hline
\end{tabular}


Begitu juga bobot kepentingan $(W)$ setiap kriteria yang ditentukan oleh pengambil keputusan dinilai dengan angka 1 (satu) sampai 5 (lima) seperti yang tertera pada tabel 3. Tingkat kepentingan akan menentukan hasil rekomendasi, dimana kriteria yang diberi bobot sangat penting berarti kriteria tersebut diperhitungkan, sedangkan kriteria yang diberi bobot tidak penting berarti kriteria tersebut diabaikan.

Tabel 3. Tabel bobot kepentingan kriteria

\begin{tabular}{cc}
\hline Bobot & Keterangan \\
\hline 1 & Tidak Penting \\
2 & Kurang Penting \\
3 & Cukup \\
4 & Penting \\
5 & Sangat Penting \\
\hline
\end{tabular}

\subsubsection{Bobot Subkriteria Durasi Perjalanan}

Subkriteria durasi perjalanan (C2) dibagi menjadi 2, yaitu subkriteria durasi perjalanan haji dan subkriteria durasi perjalanan umrah yang masing-masing bobot diperoleh dari semua data durasi perjalanan mulai yang tersingkat hingga yang paling lama dan selanjutnya dibagi menjadi beberapa range seperti yang tertera pada tabel 4 dan tabel 5.

Tabel 4. Tabel bobot subkriteria durasi perjalanan haji

\begin{tabular}{cc}
\hline Durasi Perjalanan Haji & Bobot \\
\hline 23 & 1 \\
$24-25$ & 2 \\
$26-27$ & 3 \\
$28-29$ & 4 \\
30 & 5 \\
\hline
\end{tabular}

Tabel 5. Tabel bobot subkriteria durasi perjalanan umrah

\begin{tabular}{cc}
\hline Durasi Perjalanan Umrah & Bobot \\
\hline$<10$ & 1 \\
10 & 3 \\
$>10$ & 5 \\
\hline
\end{tabular}

\subsubsection{Bobot Subkriteria Jumlah Orang Sekamar}

Bobot subkriteria jumlah orang sekamar (C3) yang masing-masing bobot diperoleh dari semua data jumlah orang sekamar mulai yang terkecil sampai terbesar selanjutnya dibagi menjadi beberapa range seperti yang tertera pada tabel 6 .

Tabel 6. Tabel bobot subkriteria jumlah orang

\begin{tabular}{cc}
\hline Jumlah Orang & Bobot \\
\hline 2 & 1 \\
3 & 3 \\
4 & 5 \\
\hline
\end{tabular}

\subsubsection{Bobot Subkriteria Fasilitas}

Berdasarkan data yang telah diperoleh, terdapat 10 fasilitas di dalam setiap paket perjalanan haji dan umrah, yaitu seperti yang tertera pada tabel 7 . 
Tabel 7. Tabel daftar fasilitas paket perjalanan

\begin{tabular}{ll}
\hline No & Fasilitas Paket Perjalanan \\
\hline 1 & Jenis Hotel Bintang \\
2 & Jenis Kelas Pesawat \\
3 & Konsumsi \\
4 & Mutawwif (Guide) \\
5 & Transportasi Bus Selama di Arab \\
6 & Ziarah Tempat Bersejarah \\
7 & Air Zamzam (Per orang) \\
8 & Perlengkapan Haji/Umrah \\
9 & Visa Haji/Umrah \\
10 & Bonus Perjalanan \\
\hline
\end{tabular}

Pada kriteria ini, setiap fasilitas pada paket perjalanan haji atau umrah akan disesuaikan rating kecocokannya dengan nilai 0 sampai 0,5 . Kemungkinan terbesar adalah 5 , yaitu jika rating kecocokan seluruh fasilitas bernilai tinggi dan kemungkinan terkecil adalah 0 , yaitu jika rating kecocokan seluruh fasilitas bernilai rendah. Sehingga akan diperoleh tabel tingkat kecocokan subkriteria fasilitas seperti yang tertera pada tabel 8 .

Tabel 8. Tabel bobot subkriteria fasilitas

\begin{tabular}{cc}
\hline Jumlah Nilai Seluruh Fasilitas & Bobot \\
\hline $0-1$ & 1 \\
$1,1-2$ & 2 \\
$2,1-3$ & 3 \\
$3,1-4$ & 4 \\
$4,1-5$ & 5 \\
\hline
\end{tabular}

\subsubsection{Alternatif}

Data alternatif yang digunakan dalam proses perekomendasian dapat dilihat pada tabel 9.

Tabel 9. Tabel alternatif

\begin{tabular}{cc}
\hline Alternatif & Kode Paket \\
\hline A1 & P0001 \\
A2 & P0004 \\
A3 & P0007 \\
A4 & P0009 \\
A5 & P0011 \\
\hline
\end{tabular}

\subsubsection{Hasil Perhitungan}

Tabel 10 merupakan data alternatif yang sudah disesuaikan rating kecocokannya pada setiap kriteria.

Tabel 10. Tabel rating kecocokan

\begin{tabular}{lllll}
\hline \multirow{2}{*}{ Alternatif } & \multicolumn{5}{c}{ Kriteria } \\
\cline { 2 - 5 } & $\boldsymbol{C 1}$ & $\boldsymbol{C 2}$ & $\boldsymbol{C 3}$ & $\boldsymbol{C 4}$ \\
\hline A1 & 12000 & 2 & 1 & 3 \\
A2 & 9700 & 2 & 1 & 4 \\
A3 & 9900 & 1 & 1 & 4 \\
A4 & 11250 & 3 & 1 & 4 \\
A5 & 9500 & 2 & 5 & 4 \\
\hline
\end{tabular}

Berikut ini merupakan normalisasi matriks yang didapat dengan memasukan rumus perhitungan berdasarkan jenis atribut biaya Min (cost) dan keuntungan Max (benefit) pada rumus (1), sehingga di dapatkan matriks untuk masing - masing alternatif. 
Matriks R :

$$
\mathrm{R}=\left(\begin{array}{llll}
0.792 & 0.5 & 1 & 0.75 \\
0.979 & 0.5 & 1 & 1 \\
0.96 & 1 & 1 & 1 \\
0.844 & 0.333 & 1 & 1 \\
1 & 0.5 & 0.2 & 1
\end{array}\right)
$$

Pengambil keputusan memberikan bobot kepentingan $(W)$ sebagai berikut:

$\mathrm{W}=\left[\begin{array}{llll}5 & 3 & 3 & 5\end{array}\right]$

Tahap selanjutnya mencari alternatif terbaik dengan menggunakan rumus (2), maka didapatkan hasil sebagai berikut:

$$
\begin{aligned}
& \mathrm{V} 1=(0.792 * 5)+(0.5 * 3)+(1 * 3)+(0.75 * 5)=12.208 \\
& \mathrm{~V} 2=(0.979 * 5)+(0.5 * 3)+(1 * 3)+(1 * 5)=14.397 \\
& \mathrm{~V} 3=(0.96 * 5)+(1 * 3)+(1 * 3)+(1 * 5)=\mathbf{1 5 . 7 9 8} \\
& \mathrm{V} 4=(0.844 * 5)+(0.333 * 3)+(1 * 3)+(1 * 5)=13.222 \\
& \mathrm{~V} 4=(1 * 5)+(0.5 * 3)+(0.2 * 3)+(1 * 5)=12.100
\end{aligned}
$$

Perhitungan diatas didapatkan hasil bahwa alternatif V3 mempunya nilai terbesar dari pada alternatif lainnya, sehingga V3 menjadi alternatif terbaik.

\subsection{Hasil Penelitian}

Alat yang digunakan dalam penelitian ini adalah komputer dengan spesifikasi cukup untuk menjalankan sistem operasi dan perangkat lunak pengembangan sistem serta koneksitas internet. Sistem Operasi dan program-program aplikasi yang dipergunakan dalam dalam pengembangan sistem ini adalah: Sistem Operasi: Windows 8.1, Text Editor: Notepad++, SQL Manager: Wampserver 2.5, Software Pendukung: Mozilla Firefox.

\subsubsection{Hasil Desain DFD}

Gambar 2 merupakan gambaran umum sistem, dimana terdapat 3 (tiga) pengguna yaitu admin, biro haji dan calon jama'ah yang masing-masing memiliki hak akses yang berbeda. Admin memiliki hak akses untuk mengelola data biro haji, data paket perjalanan, data kriteria, data subkriteria dan data normalisasi. Untuk biro haji memiliki hak akses mengelola data biro haji dan paket perjalanan masing-masing biro. Sedangkan untuk calon jama'ah hanya mempunyai hak akses untuk melakukan rekomendasi pemilihan biro dan melihat info biro haji yang sudah terdaftar di sistem.

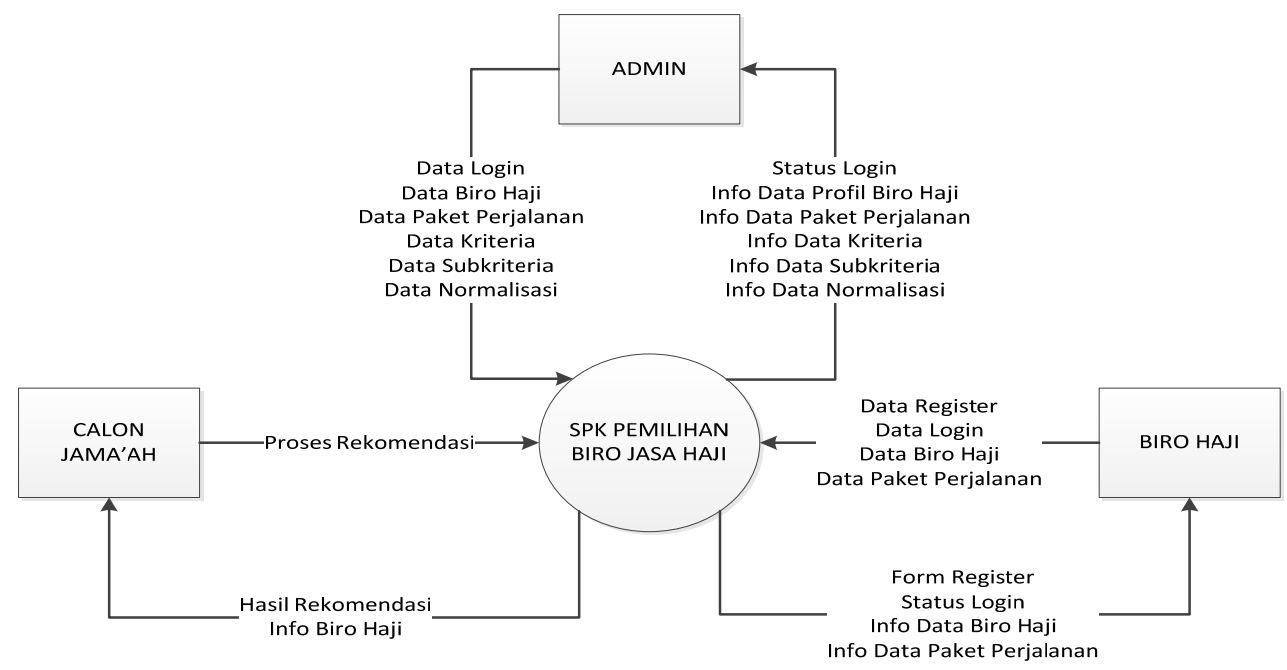

Gambar 3. Diagram Konteks 


\subsubsection{Hasil Desain Basis Data}

Relasi antar tabel pada aplikasi penelitian yang dibuat pada gambar 3 .
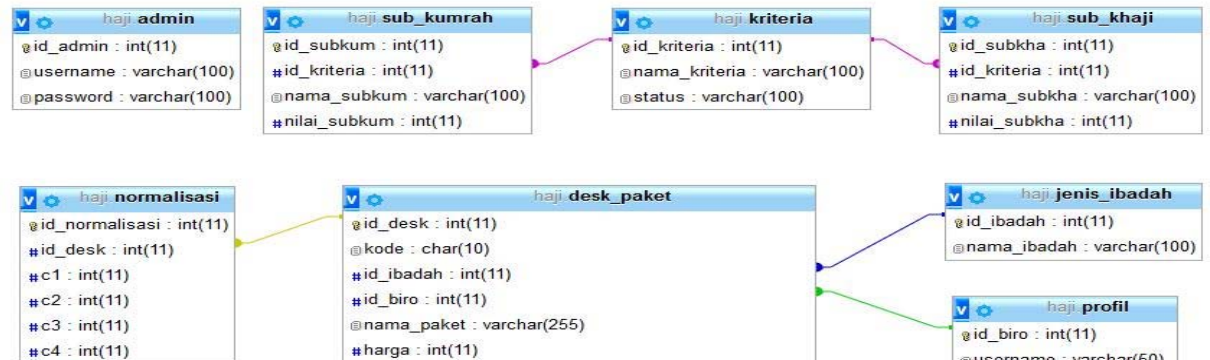

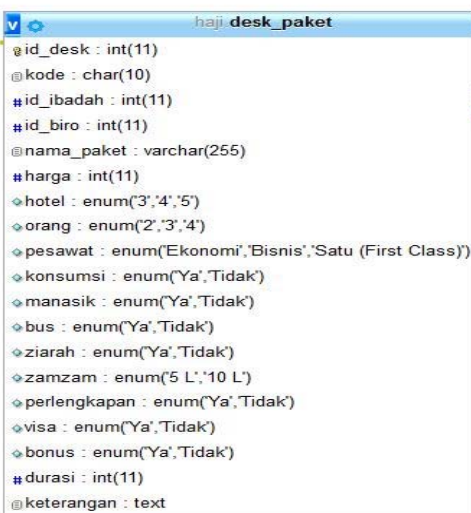

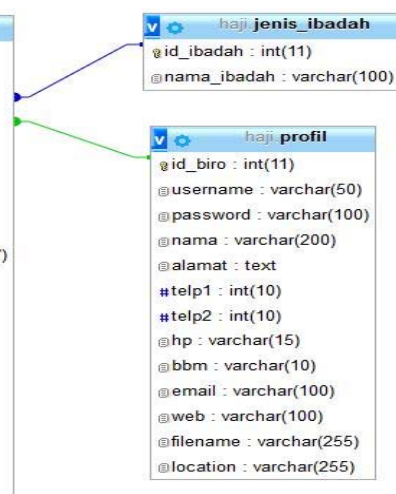

\section{Gambar 4. Relasi Antar Tabel}

\subsubsection{Antar Muka Bagian Calon Jama'ah}

Halaman utama sistem pendukung keputusan pemilihan biro perjalanan haji dan umrah di Yogyakarta dapat dilihat pada gambar 5.

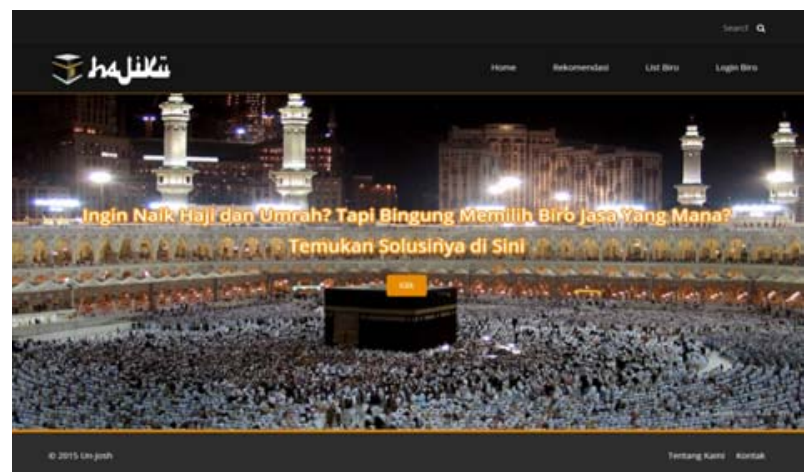

Gambar 5. Halaman Utama

Halaman proses perekomendasian biro, terdapat 3 proses, pertama menentukan jenis ibadah, kedua menentukan bobot kepentingan setiap kriteria dan terakhir hasil rekomendasi. Ketiga proses tersebut dapat dilihat pada gambar 6, 7 dan 8 . 


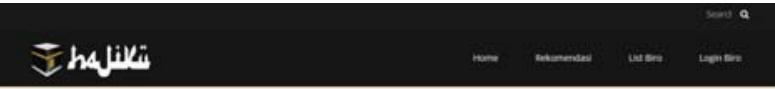

Rekomendasi Biro

Pilith Jenis Ibadah
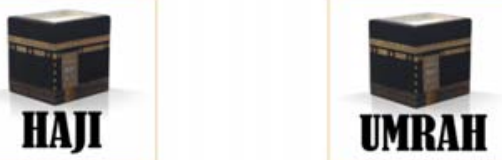

Gambar 6. Halaman Rekomendasi
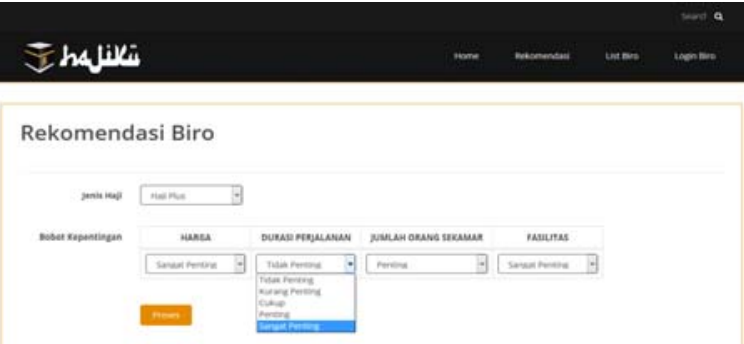

Gambar 7. Halaman Penentuan Bobot

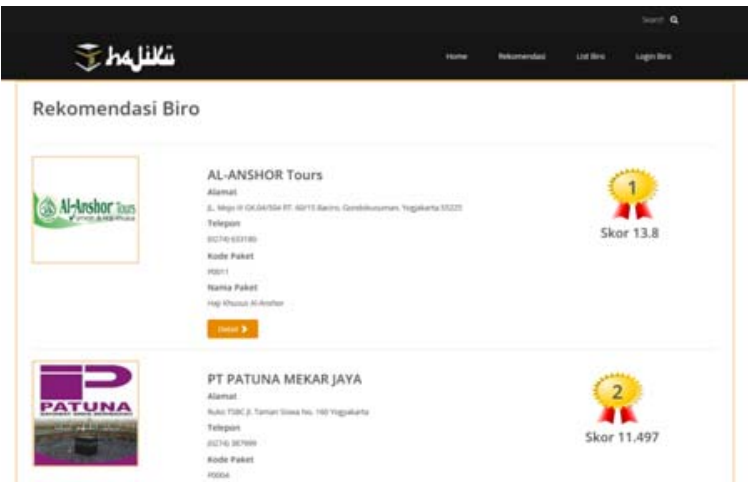

Gambar 8. Halaman Hasil Rekomendasi

\subsubsection{Antar Muka Bagian Biro Perjalanan}

Halaman login bagi biro yang sudah mempunyai akun dapat dilihat pada gambar 9 dan bagi biro yang belum mempunyai akun, sistem akan memberikan form terkait informasi biro yang harus diisi dan setelah semua form terisi selanjutnya akan diproses oleh sistem untuk disismpan didalam database. 


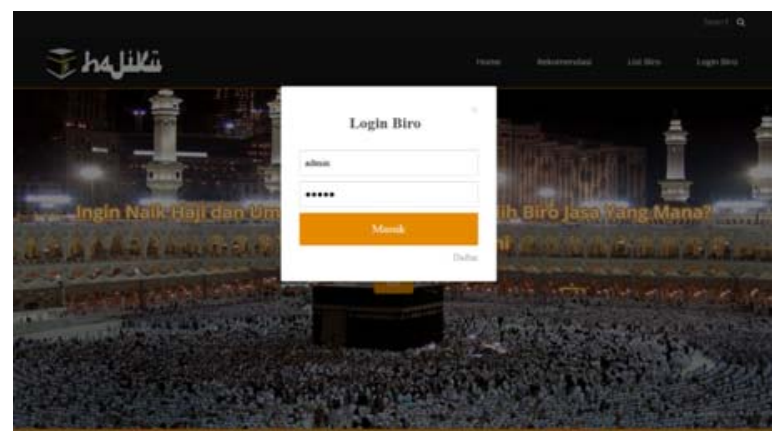

Gambar 9. Halaman Login Biro

Setelah menjadi member biro pada aplikasi tersebut, maka biro tersebut mempunyai beberapa fasilitas diantaranya, mengupload dan mengupdate profil biro dan informasi singkat paket haji/umrah masing-masing biro yang sudah disimpan disistem

\subsubsection{Antar Muka Bagian Admin}

Halaman yang pertama kali muncul setelah proses login berhasil dilakukan dapat dilihat pada Gambar 10. Admin mempunyai fasilitas mengelola data biro, data paket perjalanan, halaman kriteria, dan rating kecocokan.

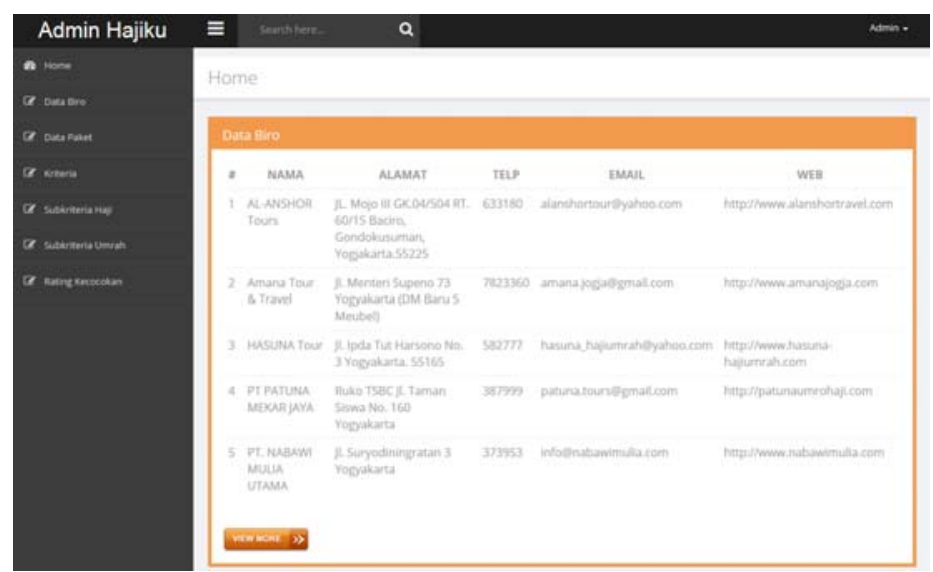

Gambar 10. Halaman Utama Admin

\subsection{Pembahasan}

Berdasarkan analisis kebutuhan sistem maka informasi yang dibutuhkan dalam membangun sistem pendukung keputusan pemilihan biro jasa perjalanan haji dan umrah adalah data profil biro dan data paket perjalanan yang dimiliki oleh biro tersebut yang bersumber dari website maupun wawancara secara langsung.

Sistem pendukung keputusan ini dapat diakses secara online dan memiliki 3 (tiga) pengguna yaitu admin, biro haji dan calon jama'ah yang masing-masing pengguna memiliki hak akses yang berbeda.

Admin memiliki hak akses untuk mengelola seluruh data baik tambah, edit dan hapus data yang ada disistem. Data yang dapat dikelola admin yaitu data profil biro, data paket perjalanan, data kriteria, data subkriteria dan data rating kecocokan.

Biro haji memiliki hak akses untuk mengelola datanya sendiri dengan cara login terlebih dahulu. Data yang dapat dikelola adalah data profil dan data paket perjalanan. Pada data profil hanya memiliki hak akses edit data sedangkan pada data paket perjalanan memiliki hak akses tambah, edit dan hapus data. Untuk biro haji yang belum mempunyai akun bisa terlebih dahulu mendaftar ke sistem untuk dapat memiliki hak akses biro yang sudah disebutkan diatas.

Calon jama'ah hanya memiliki hak akses melakukan perekomendasian dan melihat informasi profil biro yang sudah terdaftar disistem. Pada proses perekomendasian, calon jama'ah terlebih dahulu memilih jenis ibadah yang diinginkan, lalu menentukan bobot kepentingan setiap kriteria. Kriteria yang dijadikan acuan dalam proses perekomendasian ini ada 4 (empat), yaitu kriteria harga, durasi perjalanan, jumlah 
orang sekamar dan fasilitas. Selanjutnya pada tahap akhir, ketika calon jama'ah meng-klik tombol proses maka secara otomatis sistem akan memberikan alternatif terbaik yang akan dijadikan pilihan dan beberapa rekomendasi alternatif lainnya. Untuk hak akses melihat profil biro, informasi yang didapat adalah nama, foto, alamat, nomor telepon, nomor handphone, kontak bbm, email, website dan paket perjalanan yang ditawarkan.

\section{KESIMPULAN}

Berdasarkan hasil pembahasan yang telah diuraikan, maka dapat ditarik kesimpulan sebagai berikut:

1) Sistem pendukung keputusan pemilihan biro jasa perjalanan haji dan umrah di Yogyakarta yang dibangun dapat digunakan untuk membantu calon jama'ah haji maupun umrah dalam memilih biro jasa perjalanan yang sesuai dengan kriteria yang diinginkan.

2) Sistem ini juga memberi kemudahan bagi pihak biro jasa perjalanan haji dan umrah yang ada di Yogyakarta untuk berbagi informasi terbaru mengenai paket perjalanan haji maupun umrah yang ditawarkan.

3) Sistem yang telah dibuat bersifat konsultatif bertujuan sebagai alat bantu para calon jama'ah haji maupun umroh dalam membantu menentukant atau memberikan daftar rekomendasi yang paling mendekati dengan kriteria-kriteria yang diinginkan oleh calon jama'ah, adapun keputusan akhir tetap berada pada calon jama'ah sendiri.

4) Data-data yang diinputkan untuk admin adalah data kriteria, data subkriteria, data rating kecocokan, dan mengelola seluruh data yang ada diaplikasi ini, pihak biro haji menginputkana data profil biro, data paket perjalanan, dan untuk para calon jama'ah menginputkan data jenis perjalanan, data bobot kepentingan setiap kriteria yaitu kriteria harga, kriteria durasi perjalanan, kriteria jumlah orang sekamar dan kriteria fasilitas hoteldan perjalanan.

\section{DAFTAR PUSTAKA}

[1] Ariyanto. 2012. "Sistem Pendukung Keputusan Pemilihan Karyawan Terbaik Dengan Metode Simple Additive Weighting". Jurnal Tugas Akhir Universitas Islam Negeri Sunan Kalijaga Yogyakarta.

[2] Armiady, D. 2013. "Pemodelan Sistem Pendukung Keputusan Dengan Metode Kombinasi Fuzzy Tahani Dan Simple Additive Weighting”. Jurnal Tugas Akhir Universitas Sumatra Utara.

[3] Daihani. (2001). Komputerisasi Pengambilan Keputusan. Jakarta: Elex Media Komputindo.

[4] Fifiyanti, D. 2012. "Sistem Pendukung Keputusan Seleksi Dana Talangan Calon Jama'ah Haji Pada Bank Muamalat Kepri”.Jurnal Tugas Akhir Sekolah Tinggi Teknologi Indonesia Tanjungpinang.

[5] Kusumadewi, S. 2005. "Pencarian Bobot Atribut Pada Multiple Attribute Decision Making Dengan Pendekatan Obyektif Menggunakan Algoritma Genetika". Jurnal Gematika Manajemen Informatia volume 2 .

[6] Kusumadewi, S, et al. (2006). Fuzzy Multy-Attribute Decision Making. Yogyakarta: Graha Ilmu.

[7] Pressman, R, S. (2010). Software engineering A Practitioner's Approach. New York: The McGraw Hill Companies.

[8] Widyani, R., and Pribadi, M. (2007). Definisi Haji Dan Umrah. Dalam: Panduan Ibadah Haji Dan Umrah. Cirebon: Swagati Press, p.5 